\title{
Publisher Correction: Genetic tool development in marine protists: emerging model organisms for experimental cell biology
}

Drahomíra Faktorová (D, R. Ellen R. Nisbet D, José A. Fernández Robledo, Elena Casacuberta, Lisa Sudek, Andrew E. Allen (D), Manuel Ares JrD, Cristina Aresté, Cecilia Balestreri, Adrian C. Barbrook, Patrick Beardslee, Sara Bender, David S. Booth, François-Yves Bouget, Chris Bowler (ID), Susana A. Breglia, Colin Brownlee, Gertraud Burger (D), Heriberto Cerutti, Rachele Cesaroni, Miguel A. Chiurillo, Thomas Clemente, Duncan B. Coles, Jackie L. Collier (D), Elizabeth C. Cooney ID, Kathryn Coyne, Roberto Docampo (D), Christopher L. Dupont D, Virginia Edgcomb D , Elin Einarsson, Pía A. Elustondo, Fernan Federici, Veronica Freire-Beneitez, Nastasia J. Freyria (D), Kodai Fukuda, Paulo A. García, Peter R. Girguis, Fatma Gomaa, Sebastian G. Gornik (D), Jian Guo, Vladimír Hampl, Yutaka Hanawa, Esteban R. Haro-Contreras, Elisabeth Hehenberger, Andrea Highfield, Yoshihisa Hirakawa, Amanda Hopes, Christopher J. Howe (D), Ian Hu(D), Jorge Ibañez, Nicholas A. T. Irwin, Yuu Ishii iD, Natalia Ewa Janowicz, Adam C. Jones (D), Ambar Kachale, Konomi Fujimura-Kamada, Binnypreet Kaur, Jonathan Z. Kaye, Eleanna Kazana, Patrick J. Keeling, Nicole King, Lawrence A. Klobutcher, Noelia Lander, Imen Lassadi, Zhuhong Li, Senjie Lin (D), Jean-Claude Lozano, Fulei Luan, Shinichiro Maruyama (D), Tamara Matute, Cristina Miceli, Jun Minagawa (D), Mark Moosburner, Sebastián R. Najle (D), Deepak Nanjappa, Isabel C. Nimmo, Luke Noble, Anna M. G. Novák Vanclová, Mariusz Nowacki (iD, Isaac Nuñez, Arnab Pain (D), Angela Piersanti, Sandra Pucciarelli, Jan Pyrih, Joshua S. Rest, Mariana Rius, Deborah Robertson, Albane Ruaud, Iñaki Ruiz-Trillo, Monika A. Sigg, Pamela A. Silver (D), Claudio H. Slamovits, G. Jason Smith (D, Brittany N. Sprecher (D), Rowena Stern, Estienne C. Swart, Anastasios D. Tsaousis (D), Lev Tsypin (D), Aaron Turkewitz iD, Jernej Turnšek (D), Matus Valach (D), Valérie Vergé, Peter von Dassow, Tobias von der Haar (D), Ross F. Waller, Lu Wang, Xiaoxue Wen, Glen Wheeler, April Woods, Huan Zhang, Thomas Mock (D), Alexandra Z. Worden (D) and Julius Lukeš (D)

Correction to: Nature Methods https://doi.org/10.1038/s41592-020-0796-x, published online 6 April 2020.

This paper was originally published under standard Springer Nature copyright (@ The Author(s), under exclusive licence to Springer Nature America, Inc.). It is now available as an open-access paper under a Creative Commons Attribution 4.0 International license. The error has been corrected in the print, PDF and HTML versions of the article.

Open Access This article is licensed under a Creative Commons Attribution 4.0 International License, which permits use, sharing, adaptation, distribution and
reproduction in any medium or format, as long as you give appropriate credit to the original author(s) and the source, provide a link to the Creative Commons
license, and indicate if changes were made. The images or other third party material in this article are included in the article's Creative Commons license, unless
indicated otherwise in a credit line to the material. If material is not included in the article's Creative Commons license and your intended use is not permitted by statutory regula-
tion or exceeds the permitted use, you will need to obtain permission directly from the copyright holder. To view a copy of this license, visit http://creativecommons.org/licenses/
by/4.0/.
Published online: 15 April 2020
https://doi.org/10.1038/s41592-020-0828-6
(c) The Author(s) 2020

